\title{
The Understanding Of Sharia Principles On Consumption Expenditures In Disruptive Era
}

\author{
Asep Yusup Hanapia ${ }^{1}$, Ade Komaludin ${ }^{2}$, Fatimah Zahra Nasution ${ }^{3}$ and Iis Surgawati ${ }^{4}$ \\ \{fatimahzahranasution@unsil.ac.id ${ }^{3}$, Phone: +62812-2109-2136\} \\ ${ }^{1,2,3,4}$ Department of Economics, Siliwangi University, Jalan Siliwangi No.24 Kota Tasikmalaya, \\ Indonesia
}

\begin{abstract}
In Sharia economy, consumption activity is basically framed by certain Sharia principles. As the result of global economic dynamic whereas technology, innovation and creativity are all emerged in creating new paradigm in economic life, Sharia principles become more essential in firming and protecting consumption activities of a Muslim accordingly. In the challenge of this currently disruptive era, Sharia principles confirming and filtering the consumption choices made by a Muslim. In doing consumption activity, some of the Sharia principles covers justice, cleanliness and hygiene, simplicity, charity and morality. This study aims to examine consumption principles in Sharia economics. Moreover, by doing several statistical tests, this study attempts to discuss and measure the magnitude of the implementation of Sharia principles in consumption expenditures implemented by Muslim in Tasikmalaya City, West Java, Indonesia. This study used cluster sampling technique in deciding the sample size. A field survey with 117 sample from a population was used as the research method of this study. This current study takes Sharia principles as independent variable meanwhile consumption expenditure on food items, consumption expenditure on non-food items and total consumption expenditures as the dependent variables $\mathrm{Y}_{1}, \mathrm{Y}_{2}, \mathrm{Y}_{3}$ respectively. The hypotheses stated that Sharia principles affect consumption expenditures, therefore some relevant tests are essential in proving the hypotheses through scientific research systematically. The result admitted that Sharia principles are implemented by Muslim people in Tasikmalaya City. The implementation of Sharia principles has a positive and significant effect on consumption expenditures on food items of Muslim in Tasikmalaya City. The result implies great opportunities for producers in providing food products that complied with Sharia principles for Muslim consumers.
\end{abstract}

Keyword: Sharia principles, consumption expenditures, disruptive era.

\section{Introduction}

The development of economy in the global world either in theoretical or practical level shows the attention to a significant implementation of economy with religious basis. This is remarked by the rise of Islamic banks and other Islamic financial institutions. In academic level, Islamic economics theories have been presented and discussed in many schools and universities. It is very clear to say that for Muslims, religious teachings show great importance in this modern era of disruption.

The transformation of today's industries is increasingly being disrupted by new technologies and digital applications, facilitate the economic shift of old to new economy (Creamer and Amaria, 2012). This changes the financial structures, resources, cultures, values and the ideology of the people as a whole (Christensen and Overdorf, 2000). Disruptive era is not merely present's phenomena, but also covers the future days. The era of disruption with the advancing technology accordingly has not only accelerated local consumption on a 
massive scale, but is also changing the culture of a country, its economy, and its capabilities. Therefore, understanding and implementing religious principles becomes crucial in this new civilization in which transformation takes places in government, economic activities, law and administration, political activities, social relations, health care, education and business competition.

The acceleration of business transformation in this era caused the existence of new innovations, new products circulating and trading in the market as discussed by (Kilkki et al., 2018). In selecting dan deciding what to consume, a Muslim is required to consider Sharia principles toward the products or services he would like to consume. Sharia principles initially begin with the Quran, the revelation God's word, which is full of beautiful expressions and wisdom; and secondly from the Sunnah's attributions ascribed to the last messenger of Allah that characterize his ethical practices. Within Islamic framework, the goal of consumption is not to gain personal wants satisfaction per se, but is to direct the consumption in achieving the individual and social wellbeing (maslahah) and furthermore the higher purpose of achieving God's pleasure (Syaputra et al., 2014). Allah clearly mentioned in the Quran Surah Al-An'am (6:162) which is stated:

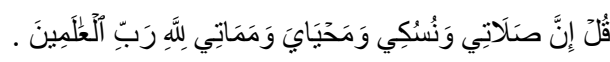

which means "Say. Surely my prayer and my sacrifice and my life and my death are (all) for Allah, the Lord of the worlds". All actions of a Muslim, including the study of economics, are directed towards a single goal (El-Karanshawy et al., 2015). The Quran and Sunnah have laid down the guiding principles in consumption that would form the framework for consumption behaviour in an Islamic economic perspective. Some of Sharia principles covers justice, cleanliness and hygiene, simplicity, charity (Hasan, 2005) and morality (Fatahillah, 2013).

Justice principle implied that consumption activities should not cause inhumanity or cruelty. Justice confirms appropriateness, properness to rules, acceptability to goodness and merits (halâlân thoyyibân). In the Quran Surah Al-Baqarah (2:168) it is stated:

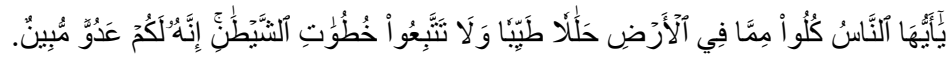

Which means "O men! eat the lawful and good things out of what is in the earth, and do not follow the footsteps of the Shaitan; surely he is your open enemy”.

In Islamic economics, it is assumed that a rational consumer will tend to screen and choose goods and services resulting maximum maslahah (Alkautsar and Hapsari, 2014). Therefore, to meet the requirements, Muslim consumer will prefer halal items and avoid haram products in his consumption baskets.

In addition to halal-haram aspect, consumption activities need to consider cleanliness and hygiene aspects of the products consumed. Cleanliness principle defines that the products consumes should fulfil the condition to the preservation of health, free from dirtiness, containing nutrition, balanced and beneficial.

Based on Sharia principle, extravagant consumption which is called isrâf and tabdzîr by which excessive spending on unimportant consumption is forbidden (Zaid Mustafar and Borhan, 2013). A Muslim consumer is expected to reduce consumption resulting uselessness. In the Quran Surah Al-A'raf (7:31) it is mentioned that:

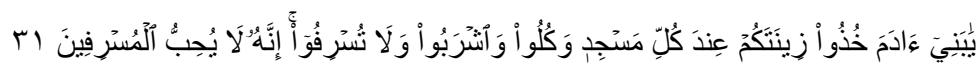


Which means "O children of Adam! attend to your embellishments at every time of prayer, and eat and drink and be not extravagant; surely He does not love the extravagant".

In the Quran Surah Al-Furqan (25:67) it is stated that:

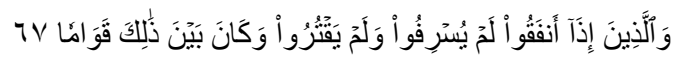

Which means: "And they who when they spend, are neither extravagant nor parsimonious, and (keep) between these the just mean".

It is firmly established that simplicity principle means the act of abstaining the extravagant spendings. In the Quran Surah Al-An'am (6:141) it is stated clearly that:

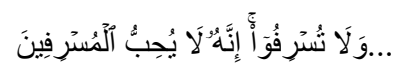

... and do not act extravagantly; surely He does not love the extravagant.

Consumption in Islam is not merely to fulfil material satisfaction of an individual but also cover social consumption in form of charities. There are two kinds of charities, i.e. compulsory charity in form of zakat and voluntary charities in forms of infaq, shadaqah, hibah, hadiyah and waqf (Awang SA, Muhammad F, Borhan JT, 2017) and (Lambarraa and Riener, 2012). As a mandatory charity, Zakat is considered as an integral part of the Islamic economic system (Ibrahim, 2015). It can play a supportive national economy improvement when consumed in productive activities (Lailatussufiani, Burhan and Multifiah, 2016). In line with zakat, voluntary charities such as infaq, shadaqah, hibah, hadiyah and waqf have many important implications and positive effects to the overall economy (Hamidah et al., 2017) and (Alvi, 2010). These generous expenditures are expected to relieve the needs of indigent, ill or helpless persons, furthermore strengthen the social as well as humanitarian linkages in the society (Khuluqo, 2016).

The last but not least, the Islamic economic agents are expected to adopt the Islamic morality principles in their actual consumption. Morality means ethics. Moral values in Islam aim to guide human activity in society, to assist and control their behavior to the benefit of the whole society and its individuals, and to bring for all individuals a good conclusion in the other life (Nuriman and Fauzan, 2017). It is implied that even in doing consumption, a Muslim is expected to uphold ethics and righteousness according to Islamic values (Furqani, 2017).

By understanding the principles, a Muslim is expected to act according to Sharia law in every aspect of his life. This study focusing on to what extent these Sharia principles affect the consumption expenditures of a Muslim in facing the challenge of this disruptive era. Clearly, for a Muslim, it is required to consider and act strategically according to Sharia principles when confronted with volatility, uncertainty, complexity, and ambiguity. In responding this current challenge, Sharia principles must be implemented as a filter in our daily activities as well as in making decision for consumption (Badawi, 2001).

This study examines the effect of Sharia principles on consumption expenditures implemented by Muslim respondents in Tasikmalaya City. This study assumes that as Muslims, respondents pay attention and responsible in considering Sharia principles in making consumption expenditures. This current study takes Sharia principles as independent variable meanwhile consumption expenditure on food items, consumption expenditure on non-food items and total consumption expenditures as the dependent variables $\mathrm{Y}_{1}, \mathrm{Y}_{2}, \mathrm{Y}_{3}$ respectively. The study framework is pictured in Figure 1. 


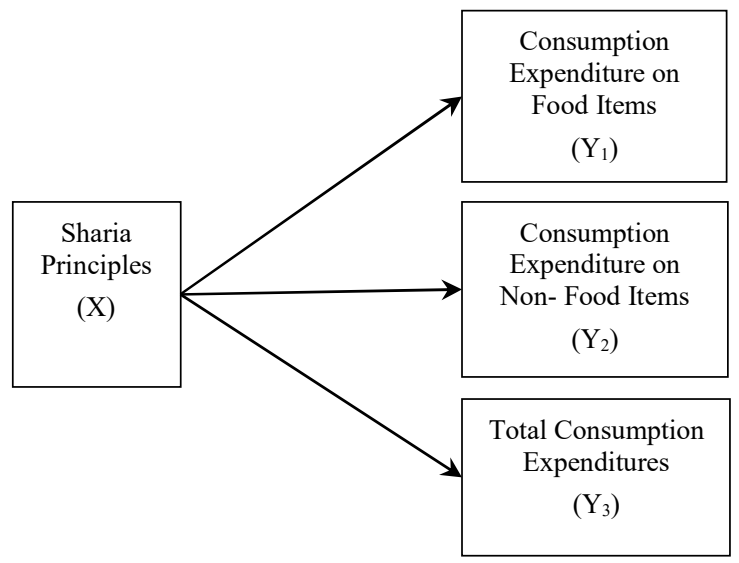

Fig. 1. Study Framework

\section{Method And Data}

This current study used quantitative approach by identifying, reviewing and elaborating literature resources of Sharia principles in consumption activities. Cluster sampling were used in drawing respondents and determining sample size respectively. The data collected through questionnaires from 117 Muslim respondents in Tasikmalaya City. The questionnaire was tested to ensure acceptability with respondents and efficiency in collecting data.

Considering the significant effect of independent variable to dependent ones, single regression analyses were run. SPSS 16.0 was used to analyze the data.

Figure 2 presents an overview of respondents' profile based on age that the majority of the respondents ranged between 41-50 years old.

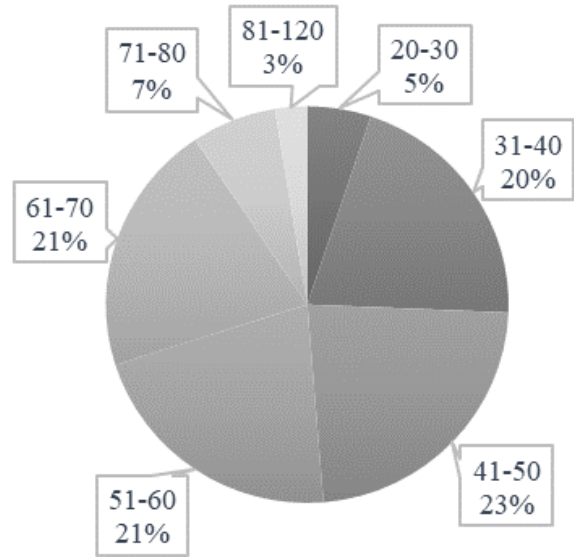

Fig. 2. Respondent Profile Based on Age

Figure 3 presents an overview of respondents' profile based on sex whereas $79 \%$ is male and $21 \%$ is female. 


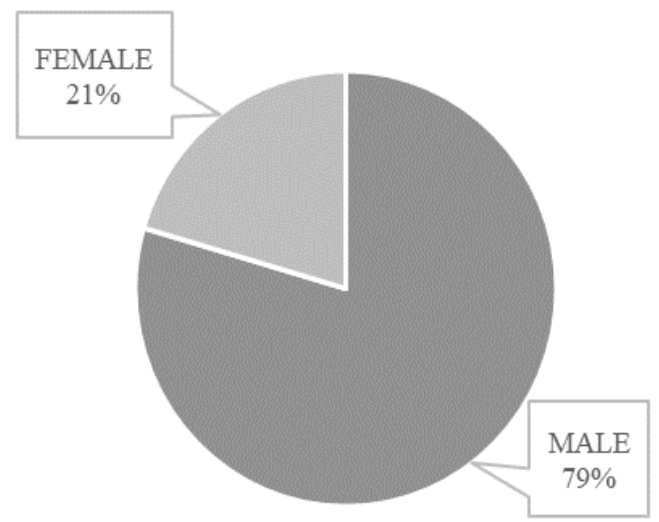

Fig. 3. Respondent Profile Based on Sex

Figure 4 presents an overview of respondents' profile based on educational level that the majority of the respondents of this study graduated from elementary school.

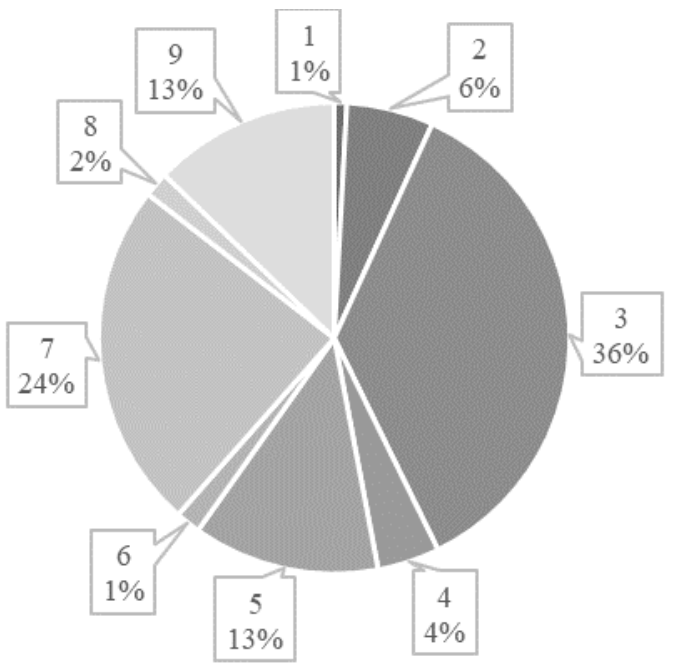

Fig. 4. Respondents' Profile Based on Educational Level

Whereas:

1. Does not go to school

2. Not graduated from elementary school

3. Graduated from elementary school

4. Not graduated from junior high school

5. Graduated from junior high school

6. Not graduated from senior high school

7. Graduated from senior high school

8. Not graduated from college

9. Graduated from college 


\section{Result And Discussion}

Islam manifests a complete code for living that is framed by Sharia principles. Islamic guidelines for all aspects of modern living are well-provided with moral instructions as discussed by (Ebrahimi, 2017). Thus, it is expected that Sharia principles are performed in every activity of a Muslim including consumption activities. According to the answer given by the respondents regarding Sharia principles in consumption activities in Tasikmalaya, the score is 29.216 with the percentage $89.18 \%$. This revealed that Sharia principles are wellimplemented by Muslims in consumption activities in Tasikmalaya City.

The magnitude of the implementation of Sharia principles (variable X) on consumption expenditures on food items (variable $\mathrm{Y}_{1}$ ), consumption expenditures on non-food items (variable $\mathrm{Y}_{2}$ ), total consumption expenditures (variable $\mathrm{Y}_{3}$ ) of Muslim in Tasikmalaya City, was observed from indicators of each variables by using simple regression analysis. The explanation of the results is as follow:

\section{a. Regression Equation}

The direct effect of the implementation of Sharia principles on consumption expenditures on food items of Muslims in Tasikmalaya City can be observed from the Coefficients output in table 1.

Table 1. Regression Coefficients of Consumption Expenditure on Food Items

\begin{tabular}{lcccrrr}
\hline \multicolumn{7}{c}{ Coefficients $^{\mathbf{a}}$} \\
\hline & \multicolumn{7}{c}{ Unstandardized Coefficients } & $\begin{array}{c}\text { Standardized } \\
\text { Coefficients }\end{array}$ & $\mathrm{t}$ & Sig. \\
\cline { 2 - 6 } & $\mathrm{B}$ & Std. Error & Beta & .473 & .637 \\
\hline 1 (Constant) & 104744.782 & 221223.837 & & 1.898 & .060 \\
\hline Sharia Principles & 2249.541 & 1185.112 & .178 & &
\end{tabular}

From table 1, the regression equation of $\mathrm{Y}_{1}$ is formed as follow:

$$
Y_{1}=104,744.782+2,249.541 X
$$

Whereas:

$$
\begin{aligned}
& \mathrm{Y}_{1}=\text { Consumption expenditures on food items } \\
& \mathrm{X}=\text { Sharia Principles } \\
& \mathrm{a}=104,744.782 \\
& \mathrm{~b}=2,249.541
\end{aligned}
$$

The regression equation stated that variable $\mathrm{X}$ (Sharia Principles) positively affects variable $\mathrm{Y}_{1}$ (Consumption expenditures on food items) as much as 2,249.541. The positive regression coefficient shows the more understanding of Sharia principles the more consumption expenditures on food items.

The direct effect of Sharia principles on consumption expenditures on non-food items of Muslims in Tasikmalaya City can be observed from the Coefficients output in table 2.

Table 2. Regression Coefficient of Consumption Expenditure on Non-Food Items

\section{Coefficients $^{\mathbf{a}}$}




\begin{tabular}{|c|c|c|c|c|c|}
\hline \multirow[t]{2}{*}{ Model } & \multicolumn{2}{|c|}{ Unstandardized Coefficients } & \multirow{2}{*}{$\begin{array}{c}\text { Standardized } \\
\text { Coefficients }\end{array}$} & \multirow[t]{2}{*}{$\mathrm{t}$} & \multirow[t]{2}{*}{ Sig. } \\
\hline & B & Std. Error & & & \\
\hline 1 (Constant) & $9.296 \mathrm{E} 7$ & $7.223 \mathrm{E} 7$ & & 1.287 & .201 \\
\hline Sharia Principles & 123764.387 & 386959.947 & .030 & .320 & .750 \\
\hline
\end{tabular}

From table 2, the regression equation of $\mathrm{Y}_{2}$ is formed as follow:

Whereas:

$$
Y_{2}=92,960,000.000+123,764.387 X
$$

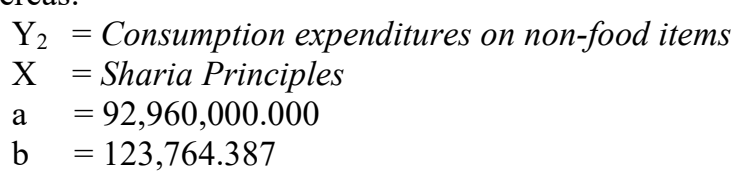

The regression equation stated that variable X (Sharia Principles) positively affects variable $\mathrm{Y}_{2}$ (Consumption expenditures on non-food items) as much as 123,764.387. The positive regression coefficient shows the more understanding of Sharia principles the more consumption expenditures on non-food items.

The direct effect of Sharia principles on total consumption expenditures of Muslims in Tasikmalaya City can be observed from the Coefficients output in table 3.

Table 3: Regression Coefficient of Total Consumption Expenditures

\begin{tabular}{|c|c|c|c|c|c|}
\hline \multicolumn{6}{|c|}{ Coefficients $^{\mathrm{a}}$} \\
\hline \multirow[b]{2}{*}{ Model } & \multicolumn{2}{|c|}{ Unstandardized Coefficients } & $\begin{array}{l}\text { Standardized } \\
\text { Coefficients }\end{array}$ & \multirow[b]{2}{*}{$\mathrm{t}$} & \multirow[b]{2}{*}{ Sig. } \\
\hline & $\mathrm{B}$ & Std. Error & Beta & & \\
\hline 1 (Constant) & 9.307E7 & $7.228 \mathrm{E} 7$ & & 1.288 & .201 \\
\hline Sharia Principles & 126013.928 & 387202.226 & .031 & .325 & .745 \\
\hline
\end{tabular}

From table 3, the regression equation of $\mathrm{Y}_{3}$ is formed as follow:

Whereas:

$$
Y_{3}=93,070,000.000+126,013.928 X
$$

$$
\begin{aligned}
\mathrm{Y}_{3} & =\text { Total consumption expenditures } \\
\mathrm{X} & =\text { Sharia Principles } \\
\mathrm{a} & =93,070,000.000 \\
\mathrm{~b} & =126,013.928
\end{aligned}
$$

The regression equation stated that variable $\mathrm{X}$ (Sharia Principles) positively affects variable $\mathrm{Y}_{3}$ (Total consumption expenditures) as much as 126,013.928.

The positive regression coefficient shows the more understanding of Sharia principles the more consumption expenditures on total consumption expenditures. 


\section{b. Coefficient of Determination}

This current study used the formula $\mathrm{kd}=\mathrm{r}^{2} \times 100 \%$ to examine the effect of the implementation of Sharia principles (variable X) on consumption expenditures on food items (variable $\mathrm{Y}_{1}$ ), consumption expenditures on non-food items (variable $\mathrm{Y}_{2}$ ), total consumption expenditures (variable $\mathrm{Y}_{3}$ ) of Muslims in Tasikmalaya City. The results are presented on table 4.

Table 4. Model Summary of Consumption Expenditures on Food Items

\begin{tabular}{|c|c|c|c|c|}
\hline \multicolumn{5}{|c|}{ Model Summary } \\
\hline Model & $\mathrm{R}$ & R Square & Adjusted R Square & $\begin{array}{l}\text { Std. Error of the } \\
\text { Estimate }\end{array}$ \\
\hline 1 & $.178^{\mathrm{a}}$ & .032 & .023 & $3.85987 \mathrm{E} 5$ \\
\hline
\end{tabular}

From table 4 , it is clear that the R-Squared value is 0.032 . The value of R-squared or Coefficient of Determination lies between $0-1$, the higher the R-Squared value, the stronger the correlation of the variables observed. The output revealed that the R-Squared is as much as $0.032=3.2 \%$. This implies that the implementation of Sharia principles of Muslim in Tasikmalaya City affects consumption expenditures on food items as much as $3.2 \%$. Meanwhile $96.8 \%$ is affected by other unobserved factors.

Table 5. Model Summary of Consumption Expenditures on Non-Food Items

\begin{tabular}{lcccc}
\hline \multicolumn{4}{c}{ Model Summary } \\
\hline Model & $\mathrm{R}$ & R Square & Adjusted R Square & $\begin{array}{c}\text { Std. Error of the } \\
\text { Estimate }\end{array}$ \\
\hline 1 & $.030^{\mathrm{a}}$ & .001 & -.008 & $1.26031 \mathrm{E} 8$ \\
\hline a. Predictors: (Constant), Sharia Principles & \\
\hline
\end{tabular}

From table 5, it is clear that the R-Squared value is 0.001 . The value of R-squared or Coefficient of Determination lies between 0 - 1, the higher the R-Squared value, the stronger the correlation of the variables observed. The output revealed that the R-Squared is as much as $0.001=0,1 \%$. This implies that the implementation of Sharia principles of Muslim in Tasikmalaya City affects consumption expenditures on non-food items as much as $0.1 \%$. Meanwhile $99.9 \%$ is affected by other unobserved factors.

Table 6. Model Summary of Total Consumption Expenditures

\begin{tabular}{lcccc}
\hline \multicolumn{4}{c}{ Model Summary } \\
\hline Model & $\mathrm{R}$ & R Square & Adjusted R Square & $\begin{array}{c}\text { Std. Error of the } \\
\text { Estimate }\end{array}$ \\
\hline 1 & $.031^{\mathrm{a}}$ & .001 & -.008 & $1.26110 \mathrm{E} 8$ \\
\hline a. Predictors: (Constant), Sharia Principles & & \\
\hline
\end{tabular}

From table 6, it is clear that the R-Squared value is 0.001 . The value of R-squared or Coefficient of Determination lies between 0 - 1, the higher the R-Squared value, the stronger the correlation of the variables observed. The output revealed that the R-Squared is as much as 
$0.001=0.1 \%$. This implies that the implementation of Sharia principles of Muslim in Tasikmalaya City affects total consumption expenditures as much as $0.1 \%$. Meanwhile $99.9 \%$ is affected by other unobserved factors.

\section{c. Hypothesis Testing}

From table 1 Regression Coefficients of Consumption Expenditure on Food Items, it is clear that $t_{\text {statistic }}$ is as much as 1.898 , meanwhile $t_{\text {table }}$ is 1.660 , with the level of significance $\alpha=$ 0.10 and Degree of Freedom $(\mathrm{df}=\mathrm{n}-\mathrm{k}-1) 112-1-1=110$. According to the calculation result, $t_{\text {statistic }}$ is greater than $t_{\text {table }}\left(t_{\text {statistic }}>t_{\text {table }}\right),=1.898>1.660$ Thus Ho is rejected. Therefore, the null hypothesis (Ho) is rejected; alternative hypothesis (Ha) is accepted. With the level of confidence $90 \%$, the implementation of Sharia principles has a positive and significant effect on consumption expenditures on food items of Muslim in Tasikmalaya City.

From Table 2 Regression Coefficient of Consumption Expenditure on Non-Food Items, it is clear that $t_{\text {statistic }}$ is as much as 0.320 meanwhile $t_{\text {table }}$ is 1.660 , with the level of significance $\alpha=0,10$ and Degree of Freedom $(\mathrm{df}=\mathrm{n}-\mathrm{k}-1) 112-1-1=110$. According to the calculation result, $\mathrm{t}_{\text {statistic }}$ is lesser than $\mathrm{t}_{\text {table }}\left(\mathrm{t}_{\text {statistic }}<\mathrm{t}_{\text {table }}\right),=0.320<1.660$ thus Ho is accepted. Therefore, the null hypothesis (Ho) is accepted; alternative hypothesis (Ha) is rejected. With the level of confidence $90 \%$, the implementation of Sharia principles affects insignificantly on consumption expenditures on non-food items of Muslim in Tasikmalaya City.

From Table 3. Regression Coefficient of Total Consumption Expenditures, it is clear that $\mathrm{t}_{\text {statistic }}$ is as much as 0.325 meanwhile $\mathrm{t}_{\text {table }}$ is 1.660 , with the level of significance $\alpha=0.10$ and Degree of Freedom $(\mathrm{df}=\mathrm{n}-\mathrm{k}-1) 112-1-1=110$. According to the calculation result, $\mathrm{t}_{\text {statistic }}$ is lesser than $\mathrm{t}_{\text {table }}\left(\mathrm{t}_{\text {statistic }}<\mathrm{t}_{\text {table }}\right),=0.325<1.660$ thus Ho is accepted. Therefore, the null hypothesis (Ho) is accepted; alternative hypothesis (Ha) is rejected. With the level of confidence $90 \%$, the implementation of Sharia principles affects insignificantly on total consumption expenditures of Muslim in Tasikmalaya City.

\section{Conclusion}

Disruptive era shows great acceleration of business transformation by which the existence of new products circulating and trading in the market is created. In selecting dan deciding what to consume, a Muslim is required to consider Sharia principles toward the products or services he would like to consume. Sharia principles play an essential role in deciding consumption expenditures of a Muslim.

Based on the statistical analysis conducted, this study established that the implementation of Sharia principles of Muslim in Tasikmalaya City affects consumption expenditures on food items, consumption expenditures on non-food items as well as total consumption expenditures. This study revealed that the implementation of Sharia principles has a positive and significant effect on consumption expenditures on food items of Muslim in Tasikmalaya City.

Results from this study ought to be interpreted within some limitations. The study was based on a small sample, did not cover all regions of Indonesia. A larger and more diverse sample could help in further ameliorating the study. Notwithstanding these limitations, findings from the study are insightful and have implications for the food industry in Tasikmalaya City and regions with similar socio-demographic attributes. Improving knowledge and horizon of Muslim people regarding Sharia principles will influence the consumption patterns. Producers also need to ensure that their products are acceptable in societies they operate in and are appropriately and adhere to religious standards. 
Finally, it is critical for food producers to invest in research and development. This would ensure the production of acceptable, suitable according to Islamic law. The result implies great opportunities for producers in providing food products that complied with Sharia principles for Muslim consumers in this ongoing disruptive era.

\section{Acknowledgement}

Researchers of this study wish to thank to The Ministries of Research, Technology and Higher Education Republic of Indonesia for the support.

\section{References}

[1] Alkautsar, Z. and Hapsari, M. I. (2014) 'Implementasi Pemahaman Konsumsi Islam pada Perilaku Konsumsi Konsumen Muslim', Jestt, 1(10), pp. 736-754.

[2] Alvi, M. H. (2010) 'Mp r a', (21465). doi: 10.3109/15368378209040332.

[3] Awang SA, Muhammad F, Borhan JT, M. M. (2017) 'The Concept of Charity in Islam: An Analysis on the Verses of the Quran and Hadith', Journal of Usuludin, 45(1), pp. 141-172. doi: 10.5829/idosi.mejsr.2013.13.e.13015.Federal.

[4] Badawi, J. A. (2001) 'Islamic Business Ethics', Spiritual Goods Faith Traditions and the Practice of Business, (January 2001), pp. 295-323. doi: 10.5840/spiritgds200127.

[5] Christensen, C. M. and Overdorf, M. (2000) 'Meeting the Challange of Disruptive Change', Harvard Business Review, pp. 1-20. doi: 10.1002/rwm3.20019.

[6] Creamer, W. and Amaria, P. (2012) 'The effect of business transformation and innovation economics on sustainable corporate competitive advantage', Research in Business \& Economics Journal, pp. 1-35. doi: 10.1016/j.clinph.2015.04.072.

[7] Ebrahimi, M. (2017) 'Islamic Identity , Ethical Principles and Human Values', 8385(December), pp. 325-336. doi: 10.26417/ejms.v6i1.p325-336.

[8] El-Karanshawy, H. A. et al. (2015) Islamic Economics: Theory, Policy and Social Justice.

[9] Fatahillah, Ik. A. (2013) 'Implementasi Konsep Etika dalam Konsumsi Perspektif Ekonomi Islam', Hukum Islam, XIII(1), pp. 154-169.

[10] Furqani, H. (2017) 'Consumption and morality: Principles and behavioral framework in Islamic economics', Journal of King Abdulaziz University, Islamic Economics, 30(Specialissue), pp. 89-102. doi: 10.4197/Islec.30-SI.6.

[11] Hamidah, R. A. et al. (2017) 'Impact of ZIS (Zakah, Infaq and Sadaqa) Distribution and Islamic Financial Institutions to MSMEs (Micro, Small, and Medium Enterprises) and Gross Regional Product Growth in East Java (2011-2014 Periods)', Journal of Islamic Financial Studies, 3(1), pp. 1-15.

[12] Haneef, M. A. and Furqani, H. (2009) 'Developing the Ethical Foundations of Islamic Economics: Benefitting from Toshihiko Izutsu', Intellectual Discourse, 17(2), pp. 173199.

[13] Hasan, Z. (2005) 'Treatment of Consumption in Islamic Economics: An Appraisal', Islamic Economy, 18(2), pp. 29-46. doi: 10.5897/JAERD12.088.

[14] Ibrahim, S. M. (2015) 'The Role of Zakat in Establishing Social Welfare and Economic Sustainability', International Journal of Management and Commerce Innovation, 3(1), pp. 437-441.

[15] Khuluqo, I. El (2016) 'The Role of Zakat in National Economic Development', International Journal of Business, Economics and Law, 9(5), pp. 214-223.

[16] Kilkki, K. et al. (2018) 'Technological Forecasting \& Social Change A disruption 
framework', Technological Forecasting \& Social Change, 129(November 2017), pp. 275-284. doi: 10.1016/j.techfore.2017.09.034.

[17] Lailatussufiani, S., Burhan, M. U. and Multifiah (2016) 'The Utilization of Zakat, Infaq and Shadaqah for Community Empowerment ( Case Study of BAZNAS West Nusa Tenggara Province )', International Journal of Business and Management Invention, 5(10), pp. 152-160.

[18] Lambarraa, F. and Riener, G. (2012) 'On the norms of charitable giving in Islam: A field experiment', Researchgate.Net, 49(0), pp. 18-24. Available at: http://www.researchgate.net/publication/45137776_Clean_evidence_on_face-toface_why_experimental_economics_is_of_interest_to_regional_economists/file/d912f5 0d1b40898b10.pdf\%5Cnhttp://www.econstor.eu/handle/10419/59571.

[19] Nuriman and Fauzan (2017) 'The Influence of Islamic Moral Values on the Students' Behavior in Aceh', Dinamika Ilmu, 17(2), pp. 275-290. doi: 10.21093/di.v17i2.835.

[20] Syaputra, E. et al. (2014) 'Maslahah as an Islamic Source and its Application in Financial Transactions', Quest Journals Journal of Research in Humanities and Social Science, 2(5), pp. 66-71. doi: 10.1016/S0959-437X(98)80109-3.

[21] Zaid Mustafar, M. and Borhan, J. T. (2013) 'Muslim Consumer Behavior: Emphasis on Ethics from Islamic Perspective', Middle-East Journal of Scientific Research, 18(9), pp. 1301-1307. doi: 10.5829/idosi.mejsr.2013.18.9.12113. 